\title{
Sınıf Öğretmeni Adaylarının Çocuk Haklarına Yönelik Tutumlarının Kültürlerarası Duyarlılık Düzeyi Bağlamında İncelenmesi
}

\section{An Investigation of Primary School Teacher Candidates' Attitudes Towards Children's Rights in Context of Intercultural Sensitivity Level}

Erdem Hareket, ${ }^{\mathrm{a}, *}$ Serhat Altıok ${ }^{\mathrm{b}}$

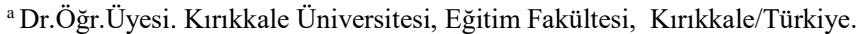
ORCID: 0000-0003-3903-7057.

bArş.Gör. , Kırıkkale Üniversitesi, Eğitim Fakültesi, Kırıkkale/Türkiye. ORCID: 0000-0001-6656-8692.

\section{MAKALE BİLGISI}

Makale Geçmişi:

Başvuru tarihi: 09 Eylül 2019

Düzeltme tarihi: 27 Kasım 2019

Kabul tarihi: 18 Aralık 2019

\section{Anahtar Kelimeler:}

Çocuk Hakları

Çocuk Haklarına Yönelik Tutum

Kültürlerarası Duyarlılık

İlişkisel Tarama
ÖZ

$\mathrm{Bu}$ araştırmada sınıf öğretmeni adaylarının, çocuk haklarına yönelik tutumlarıyla kültürlerarası duyarlılık düzeyleri arasındaki ilişki durumunun belirlenmesi amaçlanmıştır. Araştırma, nicel araştırma yaklaşımına uygun olarak ilişkisel tarama deseninde tasarlanmıştır. Araştırma örneklemini, basit seçkisiz örnekleme yoluyla belirlenmiş 419 öğretmen adayı oluşturmaktadır. Araştırmanın verileri, Kültürlerarası Duyarlılık Ölçeği ve Çocuk Haklarına İlişkin Tutum Ölçeği ile elde edilmiştir. Verilerin analizinde, parametrik ve non-parametrik testler kullanılmıştır. Araştırma sonucunda, Adayların kültürlerarası duyarlılık puanlarının cinsiyete göre anlamlı farklılaşmadığı, çocuk hakları tutum puanlarının ise kadın öğrenciler lehine anlamlı farklılaştı̆g belirlenmiştir. Adayların, kültürlerarası duyarlılık puanları ile çocuk haklarına yönelik tutum puanları arasında pozitif yönde ve orta düzeyde anlamlı ilişkinin varlığı, araştırmanın önemli bulgularından bir diğeridir. Araştırmanın sonuçları doğrultusunda, adayların çocuk haklarına yönelik tutumlarının ve kültürel farklılıklara duyarlılık düzeylerinin geliştirilmesi amacına yönelik bazı öneriler geliştirilmiştir.

\section{A B S T R A C T}

The aim of research was to determine the relationship between intercultural sensitivity and attitudes towards children's rights of primary school teacher candidates. The research has been designed in accordance with the quantitative research approach. The sample of the research consists of 419 teacher candidates. The research data were obtained by using the Intercultural Sensitivity Scale and Attitude Scale for Children's Rights. The research's data were analyzed by parametric and nonparametric tests. The result of research, it was observed intercultural sensitivity levels of primary school teacher candidates did not differ significantly according to gender. However, it was determined that attitude scores towards children's rights differ significantly in favor of female students. The another important result of the research was that there was a positive and moderate significant relationship between candidates' intercultural sensitivity scores and children's rights attitude. Based on results, some suggestions developed for purpose of improving teacher candidates' attitudes towards children's rights and sensitivity to cultural differences.

\section{Giriş}

Ayrımcılık ya da farklılıklara yönelik toleranssızlık sorunu, hâlihazırda dünya üzerinde çözülemeyen problemlerin başında gelmektedir. Bu noktada sorulması gerekli olan sorulardan bir tanesi, insanların farklı kültürlerden, dinlerden, dillerden, etnik kökenlerden ve zikredilebilecek diğer farklılık kaynaklarından hareketle ortaya koydukları bu yaklaşımlar, çocuklara yönelik olarak da gerçekleşmekte midir? Yoksa günümüzde, görmezden gelinemeyecek bir vuku alanına sahip olan hoşgörüsüz, ayrıştırıcı, ötekileştirici ve ırkçı yaklaşımlar, hiçbir dünya çocuğunun maruz

\footnotetext{
* Sorumlu yazar/Corresponding author
}

e-posta: erdemhareket@gmail.com 
kalmadığı ve kalmayacağı durumlar olarak tarif edilebilir mi? İdeleme alanı derinleştirilecek ve farklı perspektifleri temsil eden bu iki yönelim bir kenara birakılıp, "Bu sorulara verilebilecek cevapları şekillendirecek asil unsurlar nelerdir?" veya 'Bu unsurlar dolaylsiyla da cevaplar nasıl biçimlendirilebilir?', sorularına verilecek yanıtların, uç sorulara ve sonuçlarına bizzat tesir edecek dinamikleri içerdiği ön görülmektedir. $\mathrm{Bu}$ öngörüden hareketle, çocuklara ve onların haklarına olan yaklaşımların, farklı kültürlere yönelik duyarlı ve hoşgörülü olma, ayrıștırmama ve eşit kabul etme gibi yönelimlerimizle birlikte ele alınabileceğini söylemek mümkündür.

Yukarıda belirtilen bu husus, çocuk ${ }^{1}$ olgusuna ve onların sahip oldukları haklara yönelik tanımlamaların, her kültürde farklılık gösterdiği gerçeği ile birlikte ele alındığında, konunun kültür ve farklılık kavramları ile olan yakın ilişkisi daha net görülebilecektir. Çocuk ve çocukluğa ilişkin ortaya konan tanımlamalar, kültürlerarası temaslar, tarihsel olaylar ve küresel gelişmelerin güçlü etkisi ile değişkenlik gösteren bir olgu olarak günümüze süregelmiştir. Ahioğlu (2004) çocukluğun, evrensel bir tecrübe yanının varlığını vurgularken aynı zamanda kültürel bir özgünlük alanını da içerdiğini ifade etmektedir. Bu kültürel özgünlük tespitinin, korunma ihtiyaçları bulunmakla birlikte hakları olan özel insanlar olarak tarif edilmiş olan (Nacaroğlu, 2011) çocukların, dünya üzerinde çok değişken ve çeşitlilik gösteren tutum ve muamelelere maruz kalmalarına neden olan, çeşitli sebeplerle örselenen, hor görülen, dışlanan, sömürülen ya da tercih dışı seçimlere zorlanan bir profilde karşımıza çıkmalarına zemin oluşturan bir dinamik olduğunu söylemek mümkündür. Dolayısı ile çocukların ve onların haklarına yönelik yaklaşımların, kültürler ve ülkeler üstü bir anlayış ile ele alınması gerektiği vurgusunun on yedinci yüzyılın sonları kadar eski bir tarihte ortaya konulmuş olduğunun ${ }^{2}$ ne denli manidar olduğu görülmektedir. Hareket (2019), çocukların kendilerine özgü varlıkları ve hakları gözetilmeyen varlıklar olarak yaşamlarını sürdürmelerini normal gören bir anlayış ile çağdaş ve evrensel hukukun gereği olarak insan haklarına duyarlı bir toplumsal yaşam dokusunun sağlanamayacağına dikkat çekmiştir.

$\mathrm{Bu}$ noktada, çocuk haklarının korunması, geliștirilmesi ve yaygınlaştırılması amacına dönük küresel alandaki hukukî ve politik tüm çalışmaların, dünya üzerindeki farklı kültürleri kapsayıcı ve bütüncül bir perspektifin ürünü olması gayretlerinin sonucu olduğunu söylemek mümkündür. Kuşkusuz bu gayretlerin en etkili sonucu olarak, BM Genel Kurulu'nca 1989 yılında kabul edilmiş ve dünya üzerinde çok geniş bir kabul kitlesine ulaşmış olan Çocuk Hakları Evrensel Sözleşmesini, çocuk haklarının kalkanı olarak ifade etmemiz mümkündür. Yeşilkayalı ve Yıldız-Demirtaş (2016) çocuk haklarının, çocuğun insan olmasından kaynaklı sebeplerin yanı sıra, bakım ve korunma ihtiyacına sahip olmalarından kaynaklı haklar olduğunu belirtmişlerdir. $\mathrm{Bu}$ bağlamda Çocuk Hakları Evrensel Sözleşmesinin, çocukların sahip oldukları tüm insanî ve hukukî hakların korunması ve gözetilmesinin, tüm

\footnotetext{
${ }^{1}$ Birleşmiş Milletler Genel Kurulunca alınan bir karar ve Evrensel Sözleşme'de (1989) belirtildiği üzere, 18 yaşından küçük her birey, çocuk olarak kabul edilmektedir.

${ }^{2}$ Birleşmiş Milletler Genel Kurulunca alınan bir karar ve Evrensel Sözleşme'de (1989) belirtildiği üzere, 18 yaşından küçük her birey, çocuk olarak kabul edilmektedir.
}

uygarlıklar ve kültürler üstü temel güç kaynağı olduğu ifade edilebilir. Washington (2010) Sözleşme'nin, tüm dünya halklarına mensup çocuklar için aynı anlamı taşımakta ve hiçbir ayrımcılık kaynağı gözetilmeksizin hepsi için geçerli olduğunu ifade etmiştir. Dolayısı ile küresel dünya yaşamı üzerinde, çocuk haklarına yönelik tüm tutum ve yaklaşımların, içerisine kültür ve ona ilişkin unsurları da koyabileceğimiz birçok farklılık kaynağından arınmış bir yapıya sahip olması önemli bir gerekliliktir.

$\mathrm{Bu}$ durum ayrıca, küreselleşmenin de mevcut birçok getirilerinden bir tanesini ifade etmektedir. Aksoy (2012), günümüzde küreselleşmenin birçok alanda etkisini hissettirdiğini ve bunun uluslararası göç olaylarını beklendik şekilde artırarak, farklı kültürlerden insanların bir arada bulunma durumlarını sıklaştırmakta olduğunu belirtmiştir. Belirtilen bu gerekliliğin göz ardı edilmesi halinde, göç hareketlerinin arttığı, kültürel etkileşim ve entegrasyona zemin sağlayacak araçların ve hareketlerin sıklaştığı günümüz çağında, çocuk haklarına yönelik yaklaşımların, kültürel ve medeniyetler özelinde diğer yerel birçok unsur tarafından şekillendirilebileceği ihtimali ortaya çıkabilecektir. Küçük yaşta evliliğin normal karşılanabilmesi, çalışma hayatında on beş yaş altında yer alan çocuklara iş alanlarında yer verilmesi ve çatışma ortamlarında silahlı savunma gücü olarak tercih edilmeleri gibi problemler hâlihazırda bu ihtimallerin vuku bulmuş hallerine örnek olarak sunulabilirler. Tam bu noktada, farklı kültürlerin mensubu insanların bir arada yaşamalarının normalleştiği, coğrafyaların kısa seyahatler ile daraldığı ve evrensel normların temeli üzerinde dünya yaşamının sürdürülebildiği günümüz yaşam ortamında, bütün çocuklar ve onların haklarına yönelik yaklaşımlarımızı ${ }^{3}$ evrensel bir bağlam üzerine konuşlandırabilmemiz ne derece mümkün olabilmektedir... Şüphesiz bunu şekillendiren temel dinamiklerden bir tanesi, bireylerin kültür unsuru başta olmak üzere çeşitli farklılık kaynaklarına yönelik olarak gösterecekleri tolerans düzeyi ve evrensel kabulden hareketle ortaya koyacakları olumlu yaklaşımlar olarak ifade edilebilir. Abaslı ve Polat (2019), günümüz yaşamında farklı insanları tanıyan ve farklı kültürlere karşı duyarlılık gösteren bireylere duyulan ihtiyacın arttığını belirtmiş ve kültürlerarası duyarlık kavramını bu ihtiyacın bir sonucu olarak öne çıktığına dikkat çekmiştir.

Bu bağlamda, bireylerin ait oldukları kültürel bağlamın ve farklı kültürlere ilișkin yönelimlerinin, tüm dünya çocuklarının haklarına yönelik sergilenecek tutum ve algılar ile yakından ilişkili olabileceği düşüncesi akıllara gelmektedir. Farklı yetiştirilme biçimlerine, kültürel doku etkilerine ve değerlere sahip kişilerin birlikte yer aldıkları eğitim ortamları hiç kuşkusuz, yukarıda ifade edilen yakın ilişkiyi gözlemleyebileceğimiz alanlar arasında yer almaktadır. Ve bilindiği üzere, demokratik değerlerin, ilkelerin ve insan haklarına ilişkin evrensel esasların temele alınmadığı okul ortamlarında, gerek farklılık kaynaklarından gerekse de sahip olunan kültürel değer yargılarından dolayı çeşitli çatışma alanlarının oluşması kaçınılmaz olmaktadır.

\footnotetext{
${ }^{3} \mathrm{Bu}$ noktada, hiçbir ayrım gözetmeksizin tüm dünya üzerinde eşit kabul etme, herhangi bir ayrıma maruz bırakmama, evrensel kardeşliğin bir parçası olarak görme ve temel haklarını gözetme gibi tutumlara gönderme yapılmaktadır.
} 
Rengi ve Polat (2014), farklı kültürel özelliklere sahip öğretmenlerin ve öğrencilerin etkileşim ve iletişim halinde bulundukları okullarda, farklılıklardan kaynaklanacak olumsuz durumların yaşanabileceğine dikkat çekmişlerdir. $\mathrm{Bu}$ noktada, eğitim ortamlarının temel unsurlarından olan öğrencilerin (çocukların) ve öğretmenlerin, çocuk hakları konusundaki tutum ve yaklaşımlarının kültürel farklılıklara yönelik eğilimleri tarafından etki altında kalabileceği göz ardı edilmemelidir. Bu sebeple Koçak ve Özdemir (2015), eğitim-öğretim sürecinin uygulayıcıları olan öğretmenlerin ve öğretmen adaylarının, farklı kültürel birikimlere sahip insanların bir arada bulunduğu eğitim ortamlarının gereklerine uygun davranış geliştirmelerinin ve bu farklılıklara ilişkin olumlu tutumlara sahip olmalarının gerekliliğine değinmişlerdir. Kuşkusuz bu ortamın gereklerinden bir tanesi, başta kültürel farklılıklar olmak üzere dili, dini, ırkı, cinsiyeti, etnik kökeni ve mensubu olduğu coğrafya gibi ayrıştırıc1/ötekileştirici unsurlara bakmaksızın bütün çocuklara eşit muamelede bulunmak, farklılıkları toleransla karşılamak ve etkin bir biçimde haklarını işletmek olarak ifade edilebilir. Yılmaz ve Göçen (2013), öğretmenlerin sahip oldukları donanımların, öğrenci davranışları üzerinde doğrudan etki oluşturduğunu; bu doğrultuda da farklı kültürlere duyarlı bireylerin yetiştirilebilmesini, öğretmenlerin kültürlerarası duyarlılığa sahip olmaları ön koşulu ile ilişkilendirmişlerdir. Çocukların ait oldukları kültür ve aile yapısına uygun olarak yetiştirilmelerine saygı gösterilmesi ve bu unsurlardan dolayı ayrımcılığa maruz bırakılamayacakları, ancak çocuğun üstün yararı ilkesi gereğince geleneksel ve kültürel tutum ve uygulamalardan uzak bir biçimde gözetilmeleri gerektiği hususu, Çocuk Hakları Evrensel Sözleşmesi'nin muhtelif maddelerinde ${ }^{4}$ de dile getirilmiştir. Bu bağlamda, eğitim süreçlerinin odak noktası pozisyonunda bulunan çocukların, haklarına yönelik yaklaşımların herhangi bir ayrımcılık unsuru gölgesinde bırakılmaması hususunun üzerinde önemle durulması gerektiği düşünülmektedir.

$\mathrm{Bu}$ husus şüphesiz, çocukların erken yaşlarından itibaren uzun bir süreci birlikte geçirecekleri sınıf öğretmenlerinin ve adaylarının, kültürel unsurlar başta olmak üzere farklılıklara yönelik unsurlara yönelik tolerans profilleri ile yakından ilişkilidir. Bireylerin, kültür kaynaklı farklılıklara, değerlere açık, saygılı, kültürel duyarlılık sahibi kişiler olarak yetiştirilmelerinde ve eğitim-öğretim yolu ile de bu özelliklerin edindirilmesinde, öğretim programları ve ders kitapları kadar belki de en önemli rol öğretmenlere düşmektedir (Başbay ve Bektaş, 2009; Epçaçan ve Gün, 2016). Şüphesiz öğretmenlerin ve mesleğe aday sınıf öğretmenliği programı öğrencilerinin, farklı kültürlere yönelik duyarlılı̆̆a sahip olmaları, çocuklara olan yaklaşımlarının hak temelli yönünü güçlendirecek ve ayrımcılık esaslı yaklaşımların eğitim ortamlarında hayat bulmasının önüne geçilebilmiş olunabilecektir. Buradan hareketle bu çalışmanın amacı; sınıf öğretmeni adaylarının kültürlerarası duyarlılık düzeyleri ile çocuk haklarına yönelik tutum puanları arasında anlamlı bir ilişkinin olup olmadığını, ayrıca öğrencilerin kültürlerarası duyarlılık ve

\footnotetext{
${ }^{4}$ Sözleşme'nin ilgili maddelerinde (2., 20., 23., 29., ve 30. Madde), çocukların hiçbir ayrımcılığa maruz bırakılmadan Sözleşme maddelerinden yararlandırılacağının, taraf devletlerin bu taahhüt ile yükümlü bulunduklarının, çocuklara ilişskin meselelerin çözümünde, kültürel, dinsel ve dil kimliği gibi unsurlara saygılı
}

çocuk haklarına yönelik tutumlarının bazı değişkenlere göre istatistiksel olarak anlamlı fark oluşturup oluşturmadığını araştırmaktır. $\mathrm{Bu}$ amaç doğrultusunda aşağıdaki sorulara yanıt aranmıştır:

Sınıf öğretmeni adaylarının kültürlerarası duyarlılıkları ne düzeydedir?

- Sınıf öğretmeni adaylarının kültürlerarası duyarlılık puanları cinsiyete göre farklılaşmakta mıdır?

- Sınıf öğretmeni adaylarının kültürlerarası duyarlılık puanları sınıf düzeyine göre farklılaşmakta mıdır?

* Sınıf öğretmeni adaylarının çocuk haklarına yönelik tutumları ne düzeydedir?

- Sınıf öğretmeni adaylarının çocuk haklarına yönelik tutum puanları cinsiyete göre farklılaşmakta mıdır?

- Sınıf öğretmeni adaylarının çocuk haklarına yönelik tutum puanları sınıf düzeyine göre farklılaşmakta midir?

* Sınıf öğretmeni adaylarının kültürlerarası duyarlılık puanları ile çocuk haklarına yönelik tutum puanları arasında anlamlı bir ilişki var mıdır?

\section{Yöntem}

$\mathrm{Bu}$ bölümde, araştırma modeli, örneklemi, veri toplama araçları, verilerin toplanması ve analizi süreçlerine ilişkin açıklamalara yer verilmektedir.

\subsection{Araştırma Modeli}

Sınıf öğretmeni adaylarının kültürlerarası duyarlılık düzeyleri ile çocuk haklarına yönelik tutumları arasındaki ilişkinin incelenmesi amacıyla yürütülen bu araştırmada nicel araştırma yöntemlerinden biri olan ilişkisel tarama modeli kullanılmıştır. Çalışmada iki ya da daha fazla değişken arasındaki etkileşimin varlığı ve derecesini belirlemeye olanak tanıyan ilişkisel tarama modeline uygun olarak (Cohen, Manion \& Morrison, 2007; Creswell, 2015; Fraenkel, Wallen \& Hyun, 2011; Karasar, 2009) kültürlerarası duyarlılık ve çocuk haklarına yönelik tutum değişken olarak ele alınmıştır.

\subsection{Evren ve Örneklem}

Araştırmanın evrenini 2018-2019 eğitim-öğretim yılında Sınıf Eğitimi bölümünde en az iki yıldır öğrenim görmekte olan öğretmen adayları oluşturmaktadır. Araştırma örnekleminin sınıf öğretmeni adaylarından oluşturulmasının sebebi, gerek çocuk hakları gerekse de kültürlerarası duyarlılık konularındaki farkındalığın çocuklara temel eğitim düzeyinden itibaren kazandırılması gerektiği ve dolayısıyla bu konulara ilişkin tutumların, bu dönem çocuklarına hitap edecek olan öğretmen adayı gruplar açısından daha büyük öneme sahip olduğu düşüncesidir. Ülkemizde, 2019 y1lı itibariyle mevcut 206 üniversite bünyesinde 74 aktif Sınıf Eğitimi Bölümü bulunmaktadır (YÖK, 2019). Sınıf eğitimi programı için her yıl ilan edilen lisans eğitimi kontenjanları ve yerleştirme sonuçları

olunması gerektiği ve azınlık guruplarına mensup çocukların özgün değer, kültür ve inanç sistemlerini işletme haklarının bulunduğuna atıf yapılmaktadır. 
incelendiğinde bu programlara son üç yılda yaklaşı1k 17150 öğrenci yerleştirildiği belirlenmiştir (ÖSYM, 2015; 2016; 2017). Evrene ulaşmak için gerekli maliyetin büyüklüğü karşısında evreni temsil edecek güce sahip bir örneklemin belirlenmesi araştırmanın tamamlanabilmesi için önemli bir seçenek hatta çare olarak görülebilir.

Eğitim alanında örneklem belirlemek ve en düşük birim sayısını belirlemek için evrendeki birey sayısı, güvenirlik düzeyi, hata payı, evrende istenilen özelliği taşıyan bireylerin oranından yararlanılan bir formül kullanılmaktadır (Yamane, 2010). Bu ilişkisel tarama çalışması için gerekli örneklemi belirlemek amaciyla evrendeki birey sayısı $=17150$, güvenirlik düzeyi $=\% 95$ (z değeri $=1,96)$, hata payı $=\% 5$ temel alınmış ve evreni temsil edebilecek örneklem alt sınırı 376 olarak belirlenmiştir. Bu alt sınır doğrultusunda ve basit seçkisiz örnekleme yoluyla yürütülen çalışmada 599 sınıf öğretmeni adayından veri toplanmıştır. Basit seçkisiz örnekleme, evrende yer alan tüm bireylerin örnekleme seçilme şansının birbirinden bağımsız ve eşit olduğu bir yöntemdir (Büyüköztürk, Çakmak, Akgün, Karadeniz \& Demirel, 2018).

Elde edilen veriler araştırmacılar tarafindan incelendikten sonra tamamı doldurulmayan, yanlış doldurulan ve kişisel ve eğitim durumuna ilişkin bilgileri net algılanamayan veri toplama araçları hariç tutulmuş ve 419 öğretmen adayından elde edilen veriler araştırmaya dâhil edilmiştir. Araştırma için uygun görülen bu veri kümesi örneklem alt sınırı olarak belirlenen 376 değerinden büyük olduğundan örneklem yeterliliği ve evrene ilişkin kestirim ve yorumlarda bulunabilme açısından uygun görülmektedir. Örneklem grubuna ilişkin detaylar Tablo 1'de sunulmuştur.

Tablo1. Katılımcılara İlișkin Betimsel İstatistikler

$$
\text { 2. Sinıf 3. Sinıf 4. Sinıf Toplam }
$$

\begin{tabular}{ccccccccc}
\cline { 3 - 7 } Cinsiyet & $\mathbf{n}$ & $\%$ & $\mathbf{n}$ & $\%$ & $\mathbf{n}$ & $\%$ & $\mathbf{n}$ & $\%$ \\
\hline Kadın & 65 & 15,51 & 186 & 44,39 & 115 & 27,45 & 366 & $\begin{array}{c}87,3 \\
5\end{array}$ \\
Erkek & 15 & 3,58 & 22 & 5,25 & 16 & 3,82 & 53 & $\begin{array}{c}12,6 \\
5\end{array}$ \\
\hline Toplam & 80 & 19,09 & 208 & 49,64 & 131 & 31,27 & 419 & 100
\end{tabular}

Tablo 1 incelendiğinde katılımcıların büyük çoğunluğunun kadın öğretmen adaylarından (\%87) oluştuğu, erkek katılımcıların (\%13) oranının bölümde öğrenim gören öğretmen adaylarının cinsiyete göre dağılımlarına benzer biçimde düşük kaldığı görülmektedir. Araştırmaya dâhil edilen, Türkiye'nin yedi farklı coğrafi bölgesinde yer alan 13 farklı devlet üniversitesinde öğrenim gören sınıf öğretmeni adaylarının yaklaşık \%19'u ikinci sınıf, \%50'si üçüncü sınıf, $\% 31$ 'i ise dördüncü sınıfta öğrenim görmektedir.

\subsection{Veri Toplama Aracı}

Chen ve Starosta (2000) tarafindan geliştirilip, Üstün (2011) tarafından dilimize uyarlanarak, geçerlik ve güvenirlik çalıșması yapılmış olan Kültürlerarası Duyarlılık Ölçeği beşli likert tipinde dokuzu olumsuz toplam 24 ifadeden oluşmaktadır. Ölçme aracının özgün halinde "kültürlerarası etkileşime katılım", "kültürel farklılıklara saygı duyma", "kültürlerarası etkileşimde özgüven", "kültürlerarası etkileşimden zevk alma" ve "kültürlerarası etkileşime özen gösterme" olarak adlandırılmış beş boyut bulunmaktadır. Uyarlama çalışması sonucunda tek faktör altında toplam 23 ifadeden oluşan bir ölçme aracı elde edilmiștir. Ölçekten alınabilecek en düşük toplam puan 23 , en yüksek toplam puan 115 olup, yüksek toplam puan yüksek duyarlılık olarak yorumlanmaktadır. Ölçekte yer alan ifadelere örnek olarak "Farklı kültürlerden insanlarla etkileşim kurmaktan zevk alırım.", "Farklı kültürlerden insanlarla vakit geçirmekten hoşlanmıyorum." ve "Kültürel olarak farklı insanlarla uğraşmak zorunda kalacağım durumlardan kaçınırım." ifadeleri gösterilebilir. Ölçek güvenirlik ölçütlerinden olan ve iç tutarlılığı gösteren Cronbach Alpha katsayısı Chen ve Starosta (2000) tarafindan .86 olarak belirlenmiş, Üstün (2011) gerçekleştirdiği uyarlama çalışmasında .90 olarak tespit etmiş olup, bu çalışma için belirlenen iç tutarlılık katsayıs ise .89'dur.

Karaman-Kepenekçi (2006) tarafından geliştirilmiş olan Çocuk Haklarına İlişkin Tutum Ölçeği tek faktör altında yer alan üçü olumsuz toplam 22 ifadeden oluşmaktadır. Beşli likert yapıdaki ölçekten alınabilecek en düşük toplam puan 22, en yüksek toplam puan 110 olup, yüksek toplam puan olumlu tutum olarak yorumlanmaktadır. Ölçekte yer alan ifadelere örnek olarak "Çocuğun en temel hakkının "yaşama hakkı" olduğuna inanıyorum.", "Devletler farklı ülkelerde yaşayan parçalanmış ailelere bir arada yaşamaları için gerekli yardımı sağlamalıdır." ve "Çocukların savaşlardan korunmaları gerektiğine inanıyorum." ifadeleri gösterilebilir. Ölçeğin iç tutarlılık katsayısı .85 olarak belirlenmiş olup, bu çalışma için belirlenen iç tutarlılık katsayısı ise .81 'dir.

\subsection{Verilerin Toplanması ve Analizi}

Çevrimiçi form olarak uygulanan veri toplama araçları yoluyla 30 farklı üniversitede öğrenim görmekte olan sınıf öğretmeni adaylarından veri toplanmıştır. Çevrimiçi form, öğretmen adaylarına uygulanmasında ilgili üniversitelerin sınıf eğitimi anabilim dalı öğretim elemanları ve proje, etkinlik duyurmaya yönelik bir web forum yoluyla iletilmiştir. Veriler, yaklaşık dört haftalık bir zaman dilimi içerisinde elde edilmiştir. Elde edilen veri setinin analize uygun olup olmadığına karar vermek amacıyla hatalı ve eksik bilgilerin varlığg incelenmiş ve analize uygun görülmeyen veriler silinmiştir. Elde kalan verilerin araştırma için yeterliliği ise örneklem alt sınırı ile kıyaslanarak sınanmış ve verilerin bu araştırmada kullanımının uygunluğuna karar verilmiştir. Veri seti sosyal bilimler için istatistik paket programına aktarılmış ve ilk olarak veri toplama araçlarında yer alan olumsuz maddeler ters puanlanmıştır. Likert tipteki ölçek ifadelerine ilişkin kayıp verilere ortalama atamadan önce veri eksikliğinin rastgele olduğunu belirlemek amacıyla EM analizi yapılmış ve uygun görülen kayıp değerlere ortalama değer atanmıştır. Veri seti uç ve aşırı değerler açısından incelenmiş ve belirlenen az sayıda uç değerin çıkartılması ya da dâhil edilmesinin anlamlı fark oluşturmadığı görüldüğünden çıkartma işlemi yapılmadan çözümleme sürecine devam edilmiştir. Ardından kültürlerarası duyarlılık ve çocuk haklarına ilişkin tutum ölçeklerinden elde edilen puanların cinsiyet, sınıf düzeyi ve toplam puan açısından normal dağılım gösterip göstermediği 
incelenmiş ve elde edilen betimsel istatistikler Tablo 2'de sunulmuştur.

Tablo 2. Kültürlerarası Duyarlılık ve Çocuk Hakları Tutumu Puanlarına İlişkin Betimsel İstatistikler

\begin{tabular}{ccccccc}
$n$ & $\overline{\mathbf{X}}$ & SS & Çarpıkl & $\begin{array}{c}\text { Basıklı } \\
\mathbf{k}\end{array}$ & $\begin{array}{c}\text { K-S } \\
(\mathbf{p})\end{array}$ & $\begin{array}{c}\text { S- } \\
(\mathbf{p})\end{array}$ \\
\hline
\end{tabular}

Kültürlerarası Duyarlılık

\begin{tabular}{|c|c|c|c|c|c|c|c|c|}
\hline \multirow{2}{*}{$\begin{array}{c}\text { Cinsiye } \\
t\end{array}$} & Kadın & $\begin{array}{c}36 \\
6\end{array}$ & 4,16 & ,403 &,- 210 &,- 330 & ,007 & ,005 \\
\hline & Erkek & 53 & 4,20 & ,427 & ,090 &,- 083 & 053 & ,074 \\
\hline \multirow{3}{*}{$\begin{array}{c}\text { Sinıf } \\
\text { Düzeyi }\end{array}$} & $\begin{array}{c}2 . \\
\text { Sinif }\end{array}$ & 80 & 3,96 & ,412 & ,259 & ,067 & ,008 & ,060 \\
\hline & $\begin{array}{c}\text { 3. } \\
\text { Sinıf }\end{array}$ & $\begin{array}{c}20 \\
8\end{array}$ & 4,23 & ,383 &,- 228 &,- 171 & ,049 & ,066 \\
\hline & $\begin{array}{c}4 . \\
\text { Sinıf }\end{array}$ & $\begin{array}{c}13 \\
1\end{array}$ & 4,20 & ,399 &,- 211 &,- 722 & ,063 & ,030 \\
\hline \multicolumn{2}{|c|}{ Toplam } & $\begin{array}{c}41 \\
9\end{array}$ & 4,17 & ,406 &,- 164 &,- 430 & ,002 & ,001 \\
\hline
\end{tabular}

\section{Çocuk Hakları Tutumu}

\begin{tabular}{|c|c|c|c|c|c|c|c|c|}
\hline \multirow{3}{*}{ Cinsiy } & Kadın & $\begin{array}{c}36 \\
6\end{array}$ & 4,80 & ,214 & $-1,691$ & 3,548 & ,000 & ,000 \\
\hline & & & & & & & & \\
\hline & Erkek & 53 & 4,68 & ,285 & $-1,109$ & 1,622 & ,017 &, 000 \\
\hline \multirow{3}{*}{$\begin{array}{r}\text { Sinıl } \\
\text { Düze. }\end{array}$} & 2. Sinıf & 80 & 4,73 & ,260 & $-1,202$ & 1,537 & ,000 & ,000 \\
\hline & 3. Sinıf & $\begin{array}{c}20 \\
8\end{array}$ & 4,80 & ,204 & $-1,669$ & 3,720 & ,000 & ,000 \\
\hline & 4. Sinıf & 131 & 4,79 & ,239 & $-1,801$ & 3,468 & ,000 & ,000 \\
\hline \multicolumn{2}{|l|}{ Toplam } & $\begin{array}{c}41 \\
9\end{array}$ & 4,78 & ,228 & $-1,621$ & 2,963 & ,000 & ,000 \\
\hline
\end{tabular}

Tablo 2'de yer alan betimsel istatistikler, normallik testlerinden Kolmogorov-Smirnov sonuçları bağlamında ele alındığında yalnızca kültürlerarası duyarlılık puanlarının erkek cinsiyet alt puanlarının normal dağılım gösterdiği görülmektedir (<.05). Ancak, örneklem büyüklüğünün 20-50 arasında ya da 250'nin üzerinde olduğu durumlarda verilerin örneklemdeki sayıya duyarlı hale geldiğini belirten Schoder, Himmelmann ve Wilhelm (2006), bu örneklem büyüklüklerinde K-S normallik test sonuçlarının hatalı çıkma ihtimalinin yüksek olduğunu ve normallik varsayımlarının sınanmasında çarpıklık ve basıklık katsayıları temelinde, betimsel istatistikler ve grafiksel yöntemlerden yararlanılarak karar verilmesi gerektiğini önermektedir. $\mathrm{Bu}$ öneri doğrultusunda, normallik varsayımlarının sınanmasında sıfıra yakınlığı normal dağılıma işaret eden ve Tabachnick ve Fidell (2013) tarafından en fazla $\pm 1,5$ değerinde olması önerilen çarpıklık (dağılımının simetrisi) ve basıklık (dağılımın zirvesi) katsayıları temel alınmıştır. $\mathrm{Bu}$ inceleme sonucunda kültürlerarası duyarlılık puanlarının tümünün normal dağılım gösterdiği, çocuk hakları tutum puanlarının tümünün normal dağılım göstermediği belirlenmiştir. Betimsel istatistikler üzerinden yapılan değerlendirme sonuçları, analiz sırasında elde edilen grafikler (histogram, uç değerler (box-plot), normal Q-Q, detrended Q-Q vb.) ile de örtüşmektedir.

\section{Bulgular ve Yorumlar}

\section{Sınıf öğretmeni adaylarının kültürlerarası duyarlılık puanları cinsiyete göre farklılaşmakta mıdır?}

Sınıf öğretmeni adaylarının kültürlerarası duyarlılık puanlarının, cinsiyete göre anlamlı farklılık gösterip göstermediğini belirlemek amacıyla bağımsız örneklemler için T testi uygulanmış ve sonuçlar Tablo 3 'te sunulmuştur.

Tablo 3. Kültürlerarası Duyarlılık Puanlarının Cinsiyete Göre Dağılımına İlişkin Bağımsız Örneklemler İçin T-Testi Sonuçları

\begin{tabular}{lccccccc}
\hline & Grup & $\mathbf{n}$ & $\overline{\mathbf{X}}$ & SS & Sd & $\mathbf{t}$ & $\mathbf{p}$ \\
\hline & Kadın & 366 & 4,16 &, 403 & & & \\
$\begin{array}{c}\text { Külttürlerarası } \\
\text { Duyarlılık }\end{array}$ & Erkek & 53 & 4,20 &, 427 & & &
\end{tabular}

Tablo 3 incelendiğinde, sınıf öğretmeni adaylarının kültürlerarası duyarlılık puanlarının cinsiyete göre anlamlı olarak farklılaşmadığı belirlenmiştir $(\mathrm{t}(417)=, 590 ; \mathrm{p}>.05)$. Diğer bir ifade ile kadın öğretmen adaylarının kültürel duyarlılık puan ortalaması $(\overline{\mathbf{X}}=4,16)$ ile erkek öğretmen adaylarının kültürel duyarlılık puan ortalaması $(\overline{\mathbf{X}}=4,20)$ arasında herhangi bir taraf lehine istatistiksel olarak anlamlı bir fark olmadığı tespit edilmiştir.

\section{Sınıf öğretmeni adaylarının çocuk haklarına yönelik tutum puanları cinsiyete göre farklılaşmakta mıdır?}

Sınıf öğretmeni adaylarının çocuk haklarına yönelik tutum puanlarının, cinsiyete göre anlamlı farklılık gösterip göstermediğini belirlemek amacıyla Mann-Whitney U testi uygulanmış ve sonuçlar Tablo 4'te sunulmuştur.

Tablo 4. Çocuk Haklarına Yönelik Tutum Puanlarının Cinsiyete Göre Dağılımına İlişkin Mann-Whitney U Testi Sonuçları

\begin{tabular}{cccccc}
\hline & $\begin{array}{c}\text { Grup } \\
/\end{array}$ & $\begin{array}{c}\text { Sira } \\
\text { Ortalamas } \\
\mathbf{n}\end{array}$ & $\begin{array}{c}\text { Sira } \\
\text { Toplam } \\
\mathbf{1}\end{array}$ & $\mathbf{U}$ & $\mathbf{p}$ \\
\hline Çocuk & $\begin{array}{c}\text { Kadı } \\
\mathbf{n}\end{array}$ & 217,00 & 79422,5 & & \\
Haklarına & 366 & & 0 & 7136,5 & $\mathbf{, 0 0 2}$ \\
Yönelik & Erke & & & 0 & $*$ \\
Tutum & $\mathbf{k}$ & 161,65 & 8567,50 & & \\
& 53 & & & & \\
\hline
\end{tabular}

Tablo 4 incelendiğinde, sınıf öğretmeni adaylarının çocuk haklarına yönelik tutum puanlarının cinsiyete göre anlamlı olarak farklılaştığ ${ }_{1}$ belirlenmiştir [U=7136,5; $\left.\mathrm{p}<.05\right]$. Diğer bir ifade ile kadın öğretmen adaylarının çocuk haklarına yönelik tutum puan sıra ortalamalarının $(\overline{\mathbf{X}}=217,00)$ erkek öğretmen adaylarının çocuk haklarına yönelik tutum puan sıra ortalamaları $(\overline{\mathbf{X}}=161,65)$ ile arasında kadın öğretmen 
adayları lehine istatistiksel olarak anlamlı bir fark olduğu tespit edilmiştir.

\section{Sınıf öğretmeni adaylarının kültürlerarası duyarlılık puanları sınıf düzeyine göre farklılaşmakta mıdır?}

Sınıf öğretmeni adaylarının kültürlerarası duyarlılık puanlarının, sınıf düzeyine göre anlamlı farklılık gösterip göstermediğini belirlemek amacıyla tek faktörlü varyans analizi (ANOVA) testi uygulanmış ve sonuçlar Tablo 5'de sunulmuştur.

Tablo 5. Kültürlerarası Duyarlılık Puanlarının Sınıf Düzeyine Göre Dağılımına İlişkin Bağımsız Örneklemler İçin Tek Faktörlü Varyans Analizi (ANOVA) Sonuçları

\begin{tabular}{cccccc}
\hline $\begin{array}{c}\text { Varyansın } \\
\text { Kaynağı }\end{array}$ & $\begin{array}{c}\text { Kareler } \\
\text { Toplamı }\end{array}$ & Sd & $\begin{array}{c}\text { Kareler } \\
\text { Ort. }\end{array}$ & $\begin{array}{c}\text { F } \\
\mathbf{p}\end{array}$ & $\begin{array}{c}\text { Anlamlı } \\
\text { Fark }\end{array}$ \\
\hline G.Arası & 4,409 & 2 & 2,204 & & \\
G. İçi & 64,427 & 416 &, 155 & $\begin{array}{l}14,234 \\
\mathbf{0 0 0 0} *\end{array}$ & 2.- 3. Sinıf \\
& & & & & \\
Toplam & 68,836 & 418 & & &
\end{tabular}

Tablo 5 incelendiğinde, sınıf öğretmeni adaylarının kültürlerarası duyarlılık puanlarının sınıf düzeyine göre anlamlı olarak farklılaştığ 1 belirlenmiştir $[\mathrm{F}(2,416)=14,234$; $\mathrm{p}<.05]$. Birimler arası farklılığın hangi gruplar arasında olduğunu belirlemek için uygun post-hoc çoklu karşılaştırma tekniğinin belirlenmesi için Levene's testi ile grup dağılımlarının varyanslarının homojen olup olmadığı hipotezi sınanmış ve varyansların homojen olduğu saptanmıştır $(\mathrm{LF}=, 754>.05)$. Varyansların homojen olması durumunda yaygınlıkla kullanılan Scheffe çoklu karşılaştırma tekniği ile yapılan inceleme sonucunda ikinci ve üçüncü sınıf düzeyi ile ikinci ve dördüncü sınıf düzeyleri arasında anlamlı fark görüldüğü üçüncü ve dördüncü sınıf düzeyleri arasında anlamlı fark görülmediği belirlenmiştir.

\section{Sınıf öğretmeni adaylarının çocuk haklarına yönelik tutum puanları sınıf düzeyine göre farklılaşmakta mıdır?}

Sınıf öğretmeni adaylarının çocuk haklarına yönelik tutum puanlarının, sınıf düzeyine göre anlamlı farklılık gösterip göstermediğini belirlemek amacıyla Kruskal Wallis H-Testi uygulanmış ve sonuçlar Tablo 6'da sunulmuştur.

Tablo 6. Çocuk Haklarına Yönelik Tutum Puanlarının Sınıf Düzeyine Göre Dağılımına İlişkin Bağımsız Örneklemler İçin Kruskal Wallis H-Testi Sonuçları

\begin{tabular}{ccccccc}
\hline & $\begin{array}{c}\text { Sinıf } \\
\text { Düzeyi }\end{array}$ & $\begin{array}{c}\text { Sira } \\
\text { Ortalaması }\end{array}$ & $\begin{array}{c}\text { S } \\
\text { d }\end{array}$ & $\boldsymbol{x}^{\mathbf{2}}$ & $\mathbf{p}$ & $\begin{array}{c}\text { Anlaml } \\
\text { 1 Fark }\end{array}$ \\
\hline $\begin{array}{c}\text { Çocuk } \\
\text { Hakların } \\
\mathbf{a}\end{array}$ & 2. Sinıf & 185,13 & & & & \\
$\begin{array}{c}\text { Yönelik } \\
\text { Tutum }\end{array}$ & 3. Sinıf & 212,58 & 2 & 4,63 &, 09 & $\begin{array}{c}\text { Anlaml } \\
1 \text { Fark } \\
\text { Yoktur. }\end{array}$ \\
& 4. Sinıf & 221,10 & & & & \\
& & & & 4 & 9 & \\
\end{tabular}

Tablo 6 incelendiğinde sınıf öğretmeni adaylarının çocuk haklarına yönelik tutum puanlarının, sınıf düzeyine göre anlamlı farklılık göstermediği görülmektedir $\left[x^{2}(2)=4,634\right.$; $\mathrm{p}>, 05]$.

\section{Sınıf öğretmeni adaylarının kültürlerarası duyarlılık puanları ile çocuk haklarına yönelik tutum puanları arasında anlamlı bir ilişki var midır?}

Sınıf öğretmeni adaylarının kültürlerarası duyarlılık puanları ile çocuk haklarına yönelik tutum puanları arasındaki ilişkiyi belirlemek amaciyla Sperman Sira Farkları Korelasyon (rho) tekniği kullanılmış ve sonuçlar Tablo 7'de sunulmuştur.

Tablo 7. Kültürlerarası Duyarlılık Puanları ile Çocuk Haklarına Yönelik Tutum Puanlarına İlişkin Spearman Brown Sıra Farkları Korelasyon Testi Sonuçları

\begin{tabular}{cccc}
\hline & $\mathbf{n}$ & $\mathbf{r}$ & $\mathbf{p}$ \\
\hline $\begin{array}{c}\text { Kültürlerarası } \\
\text { Duyarlılık } \\
\text { Çocuk Haklarına } \\
\text { Yönelik Tutum }\end{array}$ & 419 &, 464 & $\mathbf{, 0 0 0 *}$ \\
\hline
\end{tabular}

Tablo 7 incelendiğinde, sınıf öğretmeni adaylarının kültürlerarası duyarlılık puanları ile çocuk haklarına yönelik tutum puanları arasında pozitif yönde ve orta düzeyde anlamlı bir ilişki olduğu görülmektedir.

\section{Sonuç, Tartışma ve Öneriler}

Sınıf öğretmeni adaylarının kültürlerarası duyarlılık düzeyleri ile çocuk haklarına ilişkin tutumları arasındaki ilişkinin incelenmesine yönelik olarak gerçekleştirilmiş olan bu araştırmanın sonucunda, adayların kültürlerarası duyarlılık puanlarının cinsiyet değişkenine göre anlamlı olarak farklılık taşımadığı, diğer taraftan adayların kültürlerarası duyarlılık düzeylerinin, farklı sınıf düzeylerine göre anlamlı olarak farklılık gösterdiği tespit edilmiştir. Yine araştırma sonucunda, sınıf öğretmeni adaylarının çocuk haklarına yönelik tutum puanlarının, kadın öğretmen adayları lehine istatistiksel olarak anlamlı bir fark gösterdiği ancak bu tutum puanlarının, sınıf düzeyine göre anlamlı bir farklılık göstermediği tespit edilmiştir. Adayların, kültürlerarası duyarlılık puanları ile çocuk haklarına yönelik tutum puanları arasında ise pozitif yönde (orta düzey) bir ilişkinin olduğu sonucuna ulaşılmıştır.

Araştırma sonuçları göz önüne alındığında, adayların kültürlerarası duyarlılık düzeylerinin cinsiyete göre farklılık göstermediği görülmüştür. Yılmaz ve Göçen (2013) araştırmalarında, öğretmen adaylarının kültürlerarası duyarlılık düzeylerinde, cinsiyet değişkeninin bir farklılık oluşturmadığı sonucuna ulaşmışlardır. Bu noktada sınıf öğretmeni adaylarının, farklı kültürlere ilişkin duyarlılık puanlarında anlamlı bir farklılaşmanın oluşmama sebeplerine ilişkin bazı öngörülerde bulunulması mümkündür. Adayların farklı kültürlerle etkileşim ve iletişimde bulunma durumlarına ilişkin benzer sosyal yaşantı profillerine sahip olmaları, bu öngörülerden bir tanesi olarak ifade edilebilir. Diğer bir öngörü olarak adayların farklı kültürleri tanıma, bu kültürlerden kişilerle aynı ortamlarda bulunma ve paylaşım gerçekleştirmelerini sağlayıcı eğitimsel faaliyetlerde benzer tecrübelere sahip olmaları durumu belirtilebilir. Adayların, farklı kültürlerden kişilere hoşgörülü yaklaşımlar sergileme, kültürlerarası diyalog yolları inşa etme, farklı düşüncelere ve inançlara tolerans eğilimleri noktasında benzer alg1 ve eğilimlere sahip 
olmaları, farklı bir diğer öngörü olarak ortaya konabilir. $\mathrm{Bu}$ görüşler, Öğüt ve Olkun (2018) tarafından gerçekleştirilen bir araştırmada, farklı vatandaşlığa sahip üniversite öğrencilerinin, ülkemiz vatandaşı öğrencilere kıyasla kültürlerarası iletişim süreçlerinde, kendilerinden daha çok emin, özgüvenli ve kendilerini güvende hissettikleri sonucu ile desteklenmektedir. Benzer şekilde, Bulduk, Usta ve Dinçer (2017) tarafından gerçekleştirilen araştırmada yer alan üniversite öğrencilerinin, kültürlerarası duyarlılık düzeylerinin düşük olduğu, örneklem grubunun $\% 48$ 'inin de farklı kültürden insanlar ile birlikte olmayı olumsuz bir durum olarak nitelendirdikleri ve o kültürlere ilişkin olumsuz algılara sahip oldukları görülmüştür.

Ancak erkek adayların duyarlılık düzeylerinin, kadın adaylardan yüksek olması durumunun dikkate değer bir diğer nokta olduğu da göz ardı edilmemelidir. Abaslı (2018) tarafından gerçekleştirilen bir araştırmada da, üniversite öğrencilerinin kültürlerarası duyarlılık düzeylerinin cinsiyete göre anlamlı farklılık göstermediği ancak ortalama puan düzeylerinin, erkek ve kadın öğrenciler için eşit değerde olduğu sonucuna ulaşılmıştır. $\mathrm{Bu}$ noktada değinilmesi gereken bir diğer araştırma, Abaslı ve Polat (2019) tarafindan gerçekleştirilmiştir. Üniversite öğrencileri ile gerçekleştirilen bu araştırmada, kültürlerarası duyarlılık düzeylerinin, erkek öğrencilerde anlamlı derecede yükseklik gösterdiği sonucuna ulaşılmıştır. Her ne kadar, gerçekleştirilen araştırmada cinsiyet faktörüne ilişkin anlamlı farklılık sonucuna ulaşılmamış olsa da, erkek öğrencilerin duyarlılık düzeylerindeki niceliksel farkın, değişik araştırma bulgularıyla benzerlik göstermesi önemli bir husus olarak değerlendirilmelidir. Bu noktada, " $k$ kadınlar', toplumsal yaşamımız içerisinde erkek bireylere nazaran daha örtük, gelenekçi yaklaşımların esasta tutulduğu, korumacı, farklı kültürlere yaklaşımların çeşitli düşünceler ile sınırlandırıldığı, çekimserliğe ve güvensizliğe itilen bir yaşam örgüsünün içerisinde mi yer alıyorlar?", sorusu, bu benzer araştırma sonuçlarının olası gerekçelerinin ortaya çıkarılmasında özenle üzerinde durulması gereken bir sorudur. Bu noktada ülkemiz özelinde, kırsal bölgelerde yaşayan insanların, kent yaşamına uyum sağlamış insanlara nazaran genellikle daha gelenekçi, tutucu ve farklılıkları tolerans dışı tutumlar ile karşıladıkları yönündeki tespitleri göz önünde bulundurmak önemlidir. $\mathrm{Bu}$ bağlamı kuvvetlendireceği düşünülen bir araştırmada Sezer ve Kahraman (2017), kent merkezlerinde büyüyen öğretmen adaylarının, köy ve ilçelerde büyümüş olanlara göre, kültürlerarası duyarlılık düzeylerinin daha yüksek olduğu belirlenmiştir. Bu durumu bir derece makro düzeye taşıyacak olur isek, Bozkaya ve Aydın (2010) araştırmalarında, Avrupalı öğrencilerin farklı kültürdeki kişiler ile iletişimlerinde, Türk öğrencilere kıyasla daha özgüvenli davrandıkları sonucuna ulaşmışlardır. $\mathrm{Bu}$ noktada, çocukların kendilerini ifade etme, düşüncelerini rahat dile getirme, sayg1 görme ve dikkate alınma haklarının tam olarak işletilmesinin, farklı kültürden insanlara yöneltilecek duyarlılık ve bu kişiler ile kurulacak iletişim süreçlerinin niteliği konuları ile ne derece ilişki halinde olduğu görülmektedir. $\mathrm{Bu}$ tespitten hareketle, kültürlerarası duyarlılığın ve dolayısıyla farklı kültürlere dahi ait olsalar tüm çocukların haklarına yönelik olumlu tutumların artırılmasında, çok kültürlü dünya ve toplum yapısının gerekleri gözetilerek, ilçe ve köy gibi kırsal bölge alanları özelinde eğitimsel faaliyetlerin yoğunlaştırılması gerektiği net bir şekilde ifade edilebilir.

Araştırmada ulaşılan bir diğer sonuç, adayların kültürlerarası duyarlılık puanlarının sınıf düzeyine göre farklılaştığıdır. Lisans ikinci, üçüncü ve dördüncü sınıf düzeyinde farklılaşan duyarlılık düzeyi puanları incelendiğinde, 3 . ve 4 . sınıf düzeyinde bulunan öğrencilerin kültürlerarası duyarlılık puanlarının lehine anlamlı farklılığın olduğu görülmektedir. Cetişli ve arkadaşları (2016) tarafindan gerçekleştirilen araştırmada da, hemşirelik bölümü lisans son sınıf öğrencilerinin farklı kültürlere yönelik duyarlılıklarının, birinci sınıf düzeyindeki öğrencilere göre daha yüksek olduğu sonucuna ulaşılmıştır. Benzer şekilde Akın (2016) araştırması sonucunda, öğretmen adaylarının kültürlerarası duyarlılık puanlarının, sınıf düzeyleri yükseldikçe buna paralel olarak yükseldiği sonucuna varmıştır. $\mathrm{Bu}$ araştırma sonucunun ortaya çıkmasında, sınıf düzeyi yüksek olan adayların (3. ve 4. sınıf), diğer adaylara göre farklı etnik köken ve kültürden, ulusal ya da uluslararası bölgeden ve farklı inanç/düşünce sistemine sahip gruplardan insanlar ile daha çok etkileşim ve iletişim süreçlerinde yer almış olmalarının, uluslararası seyahat ve tatiller gerçekleştirmiş olmalarının etkili olabilecek sebeplerden olabileceği ifade edilebilir. $\mathrm{Bu}$ ön görüyü güçlendirir nitelikte, Öğ̈̈ ve Olkun (2018) tarafindan gerçekleştirilen bir araştırmada ulaşılan, değişik kültürlere sahip kişilerle arkadaşlık ilişkisi bulunan üniversite öğrencilerinin, kültürel farklılıklara saygı ve pozitif duygu eğilim düzeylerinin daha yüksek olduğu sonucu belirtilebilir. McMurray (2007) araştırmasında, uluslararası seyahat deneyimi olan kolej/üniversite öğrencilerinin, deneyimsiz öğrencilere göre farklı kültürlere yönelik duyarlılıklarının daha yüksek düzeyde olduğu sonucuna dikkat çekmiştir. Benzer şekilde Saygilı ve Kana (2018) tarafindan gerçekleştirilen araştırmada, farklı kültürden bireyler ile iletişism halinde olan yabancı dil olarak Türkçe öğreticisi öğretmenlerin, kültürlerarası duyarlılık düzeylerinin yüksek düzeyde yer aldığı tespit edilmiştir. Bir diğer olası sebep olarak, lisans öğretim programlarının içeriklerine paralel olarak, öğrenciler tarafından katılım gösterilmiş olan ders, seminer ve proje benzeri içeriklerin, adayların farklı kültüre karşı duyarlı ve toleranslı olma eğilimleri noktasında bu farklılaşmaya sebep olmuş olabileceği söylenebilir. Demir ve Üstün (2017) tarafından gerçekleştirilen bir araştırmada, İngilizce öğretmenliği bölümünde öğrenim gören öğrencilerin, sınıf öğretmeni adayı öğrencilere kıyasla, kültürlerarası duyarlılık düzeylerinin anlamlı derecede yüksek olduğu sonucuna ulaşılmıştır. $\mathrm{Bu}$ sonuç, araştırmacılar tarafından beklendik olarak nitelendirilmiş, bunun gerekçesi olarak da lisans programının içeriği, amaçları, nitelik beklentileri ve çıktıları özelinde, farklı kültürlerin bir araya getirilmiş olması, kültürel zenginliğe teşvik edilme ve farklı kültürlere ön yargısız yaklaşma gibi unsurlar belirtilmiştir. Benzer şekilde Aykaç ve Aykaç (2019) araştırmalarında, çeşitli yöntemlere dayalı eğitim etkinliklerine katılım göstermiş kişilerin, farklı kültürlere

\footnotetext{
${ }^{5} \mathrm{Bu}$ noktada belirtilmek istenen özne, bahsi geçen araştırmaların örneklemlerini ve/veya bir bölümünü oluşturan kadın üniversite öğrencileridir.
} 
yönelik duyarlılıklarının ve farkındalıklarının daha yüksek olduğu sonucuna dikkat çekmişlerdir.

Araştırmada ulaşılan en dikkate değer sonuçlardan bir tanesi, öğretmen adaylarının çocuk haklarına yönelik tutumlarının cinsiyet değişkenine göre farklılaşarak, kadın öğretmen adayları lehine anlamlı fark gösterdiğidir. Bu noktada, çocuk haklarına yönelik kadın öğretmen adaylarının lehine ortaya çıkan tutum puanlarındaki anlamlı farkın oluşma sebeplerine yönelik çeşitli öngörülerde bulunulması mümkündür. Kadın mizaç yapısının, ağırlıklı olarak duyuşsal özellikler ekseninde şekillenmiş olduğu ve bu nedenle çocuklara ilişkin konulara daha hassas, korumacı ve duyarlı yaklaşımlar sergileyebilecekleri, bu öngörülerden bir tanesi olarak ifade edilebilir. Çeşitli araştırmalarda öğretmenlik mesleğinin, bireyler tarafından bir kadın mesleği olarak algılandığ1 ve toplumsal yaşamımız içerisinde, kadınlara bu yönde ulaştırılan duygu ve düşüncelerin (onlar senin de çocukların sayılır, onların senin sevgine ve ilgine ihtiyaçları var vb.) etki potansiyeli göz önüne alındığında, çocuklara yönelik geliştirilecek hoşgörü, merhamet ve sevgi duygularının, araştırmada ortaya çıkan bu anlamlı farklılığın sebeplerinden olabileceği söylenebilir.

Diğer taraftan araştırmada, sınıf öğretmeni adaylarının çocuk haklarına yönelik tutum puanlarının, sınıf düzeyine göre anlamlı farklılık göstermediği ancak sınıf düzeyindeki yükseliş ile sıra ortalamaları değerlerindeki artışın paralellik gösterdiği sonucuna ulaşılmıştır. Bu sonucun ortaya çıkmış olma sebeplerine yönelik olarak, bütün sınıf düzeylerinde yer alan adayların, aynı/benzer öğretim programlarında yer alan lisans derslerine katılım göstermiş olmaları, dolayısıyla da çocuk hakları konusundaki farkındalık ve bilgi düzeylerinin benzer noktalarda yer alması düşüncesi ileri sürülebilir. Bir diğer gerekçe öngörüsü olarak, üçüncü ve dördüncü sınıf düzeyinde öğrenim görmekte olan adayların ise tutum puanlarına yönelik sıra ortalaması değerlerinin daha yüksek olmasında, okul deneyimi, topluma hizmet uygulamaları ve öğretmenlik uygulaması dersleri kapsamında yürütülen faaliyetlerin ${ }^{6}$ etkili olmuş olabileceği söylenebilir.

Son olarak, sınıf öğretmeni adaylarının kültürlerarası duyarlılık puanları ile çocuk haklarına yönelik tutum puanları arasında pozitif yönlü anlamlı bir ilişkinin varlığı; araştırmanın en önemli sonuçlarından bir tanesi olarak ifade edilebilir. Bu araştırma sonucunun ortaya çıkmış olmasında, çocuklara ve onların haklarına yönelik konuların, bütün kültürlerde yer alması, bu konulara ilişkin çalışmaların evrensel nitelik taşıması ve dolayısıyla farklı kültürlere ve o kültürün insanlarına yönelik duyarlılığın, öğretmen adayları tarafindan çocuk öznesi ${ }^{7}$ ile özdeşleştirilmesinin etkili olabileceği söylenebilir. Bir diğer öngörü olarak, bir süredir ülkemiz içerisine farklı ülkelerden gerçekleşmekte olan diş göçler neticesinde, eğitim kurumlarımızda ki mülteci çocuk sayısındaki artışların ele alınması mümkündür. Öğretmen adaylarının üçüncü ve son sınıf düzeylerinde katılım gösterdikleri uygulama derslerinde, mülteci çocuk profilleri ile karşılaşmış olma ihtimallerinin büyüklüğü, bu noktayı irdeleme alanı olarak işaret etmektedir. Bu noktada, referans

\footnotetext{
${ }^{6} \mathrm{Bu}$ noktada ifade edilen faaliyet sözcüğü ile çocuklara ve onların haklarına yönelik farkındalık kazandırıcı, çocuklarla çeşitli çalışmalar yürütmek ve onlarla yakınlık kurmaya olanak sağlayan, çocukların nitelikli eğitim alma hakkının işletilmesine yönelik ve
}

olarak gösterilebilecek bir araştırmada sınıf öğretmenlerinin, kültürlerarası duyarlılık düzeylerine ilişkin ulaşılan yüksek değerlerin dayanağı olarak, kültürel farklılık gösteren öğrencilere ve onların bu farklılıklarına yönelik, sınıf öğretmenlerinin duyarlı tutumlar sergilemeye ilişkin yatkınlıkları gösterilmiştir (Rengi ve Polat, 2014). Adayların, sınıf düzeyi değişkenine göre de, çocuk hakları tutumlarının ve kültürlerarası duyarlılık puanlarının artış bulguları ile ortaya konmuş olması, belirtilen işaret alanının dikkate değerliğini güçlendirmektedir. $\mathrm{Bu}$ bağlamda adayların, farklı kültürlerden olan mülteci çocuklar ile gerçekleştirdikleri etkileşim ve iletişim süreçlerinin, gerek çocuk haklarına gerekse de kültürel duyarlılık durumuna paralel yönde etki etmiş olabileceği ileri sürülebilir.

$>$ Araştırmada ulaşılan sonuçlar doğrultusunda geliştirilebilecek öneriler şu şekildedir:

Sınıf öğretmenliği programında öğrenimlerini sürdüren lisans öğrencilerinin, kültürlerarası duyarlılık düzeylerini geliştirici eğitimsel faaliyetlerde bulunulabilir. $\mathrm{Bu}$ faaliyetlerin özellikle, farklı kültürlerden kişilerin katılımı ile daha etkili sonuçlar doğurabileceği düşünülmektedir.

$>$ Yine sınıf öğretmeni adaylarının çocuk hakları konusundaki bilgi düzeylerinin ve farkındalıklarının geliştirilmesine yönelik çalışmalar yürütülebilir. Bu kapsamda eğitim seminerleri, öğretim materyalleri, konferanslar ve projeler geliştirilebilir.

> Öğretmen adaylarının çocuk haklarına ve farklı kültürlere ilişkin duyarlılıklarının ve tutumlarının geliştirilmesi amacına yönelik ortaya konabilecek araçların etkililik durumlarının incelenmesine yönelik eylem araştırmaları gerçekleştirilebilir.

$>$ Çocuk haklarına yönelik tutum ile kültürlerarası duyarlılık düzeyi arasındaki ilişkinin farklı değişkenler açısından ele alınacağ çalışmalar gerçekleştirilebilir.

> Kültürlerarası duyarlılık unsuru ile çocuk haklarına ilişkin tutumların ilişki noktalarına yönelik kapsam alanı daha derin nitel araştırmalar gerçekleştirilebilir (gömülü teori, vaka çalışmaları vb.)

\section{Kaynakça}

Abaslı, K. (2018). Kültürlerarası duyarlılık ve empati arasındaki ilişkilerin Türk ve uluslararası öğrenci görüşlerine göre incelenmesi. TÜBAV Bilim Dergisi, 11(2), 20-23.

Abaslı, K. \& Polat, Ş. (2019). Öğrencilerin kültürlerarası duyarlılık ve kültürel zekâya ilişkin görüşlerinin incelenmesi. Anemon Muş Alparslan Üniversitesi Sosyal Bilimler Dergisi, 7(1) 193-202

Ahioğlu, N. (2004). Çocuklar ve küreselleşme. Ankara Üniversitesi Ĕgitim Bilimleri Fakültesi Dergisi, 37(1), 141-155.

çocuklarla ilgili konulara dikkat çekici ve katkı sağlayıcı çalışmalara atıf yapılmaktadır.

7 Çocuk öznesi kavramı, çocuklara yönelik olarak atfedilen masumiyet, temizlik, eşit küçük insanlar vb. özelliklere ilişkin anlamları çağrıştırma amacı ile kullanılmıştır. 
Aksoy, Z. (2012). Uluslararası göç ve kültürlerarası iletişim. Uluslararası Sosyal Araştırmalar Dergisi, 5(20), 292-303.

Akın, E. (2016). Türkçe öğretmen adaylarının kültürlerarası duyarlılıklarının çeşitli değişkenler açısından incelenmesi. Turkish Studies, 11(3), 29-42.

Aykaç, M. \& Aykaç, N. (2019). Yaratıcı drama temelli etkinliklerin kültürlerarası duyarlılık ve göçmen algısı üzerine etkisi. Yaratıcı Drama Dergisi, 14(1), 73-98.

Başbay, A. \& Bektaş, Y. (2009). Çokkültürlülük bağlamında öğretim ortamı ve öğretmen yeterlikleri. Ĕgitim ve Bilim, 34(152), 31-43.

Bozkaya, M. \& Aydın, İ. E. (2010). Kültürlerarası iletişim kaygısı: Anadolu Üniversitesi Erasmus öğrencileri değişim programı örneği. Istanbul Üniversitesi İletişim Fakültesi Dergisi, 1(39), 29-42.

Bulduk, S., Usta, E. \& Dinçer, Y. (2017). Kültürlerarası duyarlılık ve etkileyen faktörlerin belirlenmesi: Bir sağlık hizmetleri meslek yüksekokulu örneği. Düzce Üniversitesi Să̆llk Bilimleri Enstitüsü Dergisi, 7(2), 73-77.

Büyüköztürk, Ş., Çakmak, E. K., Akgün, Ö. E., Karadeniz, Ş. \& Demirel, F. (2018). Bilimsel araştırma yöntemleri (25. Baskı): Ankara: PegemA.

Cetişli, N. E., Işık, G., Öztornacı, B. Ö., Ardahan, E., Uran, B. N. Ö., Top, E. D. \& Avdal, E. Ü. (2016). Hemşirelik öğrencilerinin empati düzeylerine göre kültürlerarası duyarlılıkları. İzmir Kâtip Çelebi Üniversitesi Săglık Bilimleri Fakültesi Dergisi, 1(1), 27-33.

Chen, G.-M. \& Starosta, W. J. (2000). The development and validation of the intercultural sensitivity scale. Human Communication, 3, 1-15.

Cohen, L., Manion, L. \& Morrison, K. (2007). Research methods in education (6th Edition): Routledge.

Creswell, J. W. (2015). Educational research: Planning, conducting, and evaluating quantitative (5th Edition): Boston: Pearson Education, Inc.

Demir, S. \& Üstün, E. (2017). Öğretmen adaylarının, kültürlerarası duyarlılık ve etnik merkezcilik düzeylerinin incelenmesi, İn̈nü Üniversitesi Eğitim Fakültesi Dergisi. 18(3), 01-11. DOI: 10.17679/inuefd.354129

Epçaçan, C. \& Gün, M. (2016). Türkçe öğretmen adaylarının kültürlerarası duyarlılıklarının çeşitli değişkenler açısından incelenmesi (Siirt Üniversitesi Örneği). Turkish Studies, 1(3), 29-42.

Fraenkel, J. R., Wallen, N. E. \& Hyun, H. H. (2011). How to design and evaluate research in education: New York: McGraw-Hill Humanities/Social Sciences/Languages.

Hareket, E. (2019). Temel eğitim bölümü öğrencilerinin çocuk haklarına yönelik bilişsel algıları. Başkent University Journal of Education, 6(2), 167-180
Karaman-Kepenekci, Y. (2006). A study of university students' attitudes towards children's rights in Turkey. The International Journal of Children's Rights, 14(3), 307-319.

Karasar, N. (2009). Bilimsel araştırma yöntemi: Kavramlarilkeler-teknikler: Nobel Yayın Dağıtım.

Koçak, S. \& Özdemir, M. (2015). Öğretmen adaylarının çok kültürlü eğitime yönelik tutumlarında kültürel zekânın rolü. İlkögretim Online, 14(4), 1352-1369.

McMurray, A. A. (2007). Measuring intercultural sensitivity of international and domestic college students: The impact of international travel. Master's thesis, University of Florida.

Nacaroğlu, D. (2011). Medyada çocuk hakları istismarı. Çocuk haklarl ve medya el kitabı, Mustafa Ruhi Şirin (haz.), İstanbul: Çocuk Vakfı Yayınları

Öğüt, N. \& Olkun, E. O. (2018). Üniversite öğrencilerinin kültürlerarası duyarlılık düzeyi: Selçuk Üniversitesi Örneği. Selçuk Üniversitesi İletişim Fakültesi Akademik Dergisi, 11(2), 54-73.

Ölçme, Seçme ve Yerleştirme Merkezi [ÖSYM]. (2015). Yükseköğretim Programları ve Kontenjanları Kilavuzu. https://www.osym.gov.tr/TR,50/2015osys-yuksekogretim-programlari-ve-kontenjanlarikilavuzu.html adresinden 17.06.2019 tarihinde erişilmiştir.

Ölçme, Seçme ve Yerleştirme Merkezi [ÖSYM]. (2016). Yükseköğretim Programları ve Kontenjanları Kilavuzu. https://www.osym.gov.tr/TR,12454/2016-osysyuksekogretim-programlari-ve-kontenjanlarikilavuzu.html adresinden 17.06.2019 tarihinde erişilmiştir.

Ölçme, Seçme ve Yerleştirme Merkezi [ÖSYM]. (2017). Yükseköğretim Programları ve Kontenjanları Kilavuzu. https://www.osym.gov.tr/TR,13263/2017-osysyuksekogretim-programlari-ve-kontenjanlarikilavuzu.html adresinden 17.06.2019 tarihinde erişilmiştir.

Rengi, Ö. \& Polat, S. (2014). Sınıf öğretmenlerinin kültürel farklılık algıları ve kültürlerarası duyarlılıkları. Journal of World of Turks, 6(3), 135-156.

Saygılı, D. \& Kana, F. (2018). Yabancı dil olarak Türkçe öğreten öğretmenlerin kültürlerarası duyarlılığı. Ana Dili Eğitimi Dergisi, 6(4), 1041-1063.

Schoder, V., Himmelmann, A. \& Wilhelm, K. P. (2006). Preliminary testing for normality: Some statistical aspects of a common concept. Clinical and Experimental Dermatology: Clinical Dermatology, 31(6), 757-761.

Sezer, G. O. \& Kahraman, P. B. (2017). Sinıf ve okul öncesi öğretmen adaylarının çok kültürlü eğitime yönelik tutumları ile kültürlerarası duyarlılıkları arasındaki ilişki: Uludağ Üniversitesi Örneği. Mersin Üniversitesi Ĕ̈itim Fakültesi Dergisi, 13(2), 550560. 
Tabachnick, B. G. \& Fidell, L. S. (2013). Using multivariate statistics (6th Ed.). Pearson, Boston.

Üstün, E. (2011). Öğretmen adaylarının kültürlerarası duyarlılık ve etnikmerkezcilik düzeylerini etkileyen etmenler. Yayınlanmamış Yüksek Lisans Tezi, İstanbul: YTÜ

Washington, F. (2010). 5-6 Yaş grubu çocuklarına uygulanan aile katılımlı çocuk hakları eğitimi programının etkililiğinin incelenmesi. Yayınlanmamış Yüksek Lisans Tezi, İstanbul: Marmara Üniversitesi Eğitim Bilimleri Enstitüsü.

Yamane, T. (2010). Temel örnekleme yöntemleri (3. Bask1) (A. Esin, M. A. Bakır, C. Aydın, \& E. Gürbüzsel, Çev.): Literatür Yayıncılık Dağıtım.
Yeşilkayalı, E. \& Yııldız-Demirtaş, V. (2016). İlköğretim öğrencilerinin ebeveynlerinin çocuk haklarına yönelik tutumları. Batı Anadolu Eğitim Bilimleri Dergisi, 7(13), 119-140.

Yılmaz, F. \& Göçen, S. (2013). Sınıf öğretmeni adaylarının kültürlerarası duyarlılık hakkındaki görüşlerinin farklı değişkenlere göre incelenmesi. Adıyaman Üniversitesi Sosyal Bilimler Enstitüsü Dergisi, (15), 373-392.

Yükseköğretim Kurulu [YÖK]. (2019). Yükseköğretim Bilgi Yönetim Sistemi. s://istatistik.yok.gov.tr/ adresinden 02.06.2019 tarihinde edinilmiştir 